JPE (Jurnal Pendidikan Edutama) Vol. 6 No. 1 Januari 2019

P-ISSN : 2339-2258 (Print) E-ISSN: 2548-821X (Online)

http://ejurnal.ikippgribojonegoro.ac.id/index.php/JPE

\title{
PENGARUH MODEL PEMBELAJARAN DISCOVERY LEARNING TERHADAP PEMAHAMAN KONSEP MATEMATIKA
}

\author{
Miftahus Surur ${ }^{1)}$, Sofi Tri Oktavia ${ }^{2)}$ \\ ${ }^{1}$ Dosen Prodi Pendidikan Ekonomi, STKIP PGRI Situbondo \\ Email: surur99@stkippgri-situbondo.ac.id \\ ${ }^{2}$ Mahasiswa Prodi Pendidikan Ekonomi, STKIP PGRI Situbondo \\ Email:sofitrioktavia7@gmail.com
}

\begin{abstract}
This study aims to determine the difference in understanding of students' concepts in mathematics subjects using discovery learning models and direct teaching models in class $X$ of Khamas Asembagus Vocational School 2017/2018 academic year. This research is a type of quasi experiment research (quasi experiment). The population in this study was class $X$ of the Khamas Asembagus Vocational School which consisted of 3 classes with 80 students. The sample in this study is class X TKJ 1 as many as 24 students as the experimental class and class X MM as many as 31 students as the control class. Data collection in this study was conducted using a test and then analyzed by t-test. The results of the analysis show that tcount>ttable or 3.198>1.6741, it can be concluded that there is a significant difference in the level of understanding of students' concepts in mathematics between those using the discovery learning model and the direct teaching model.
\end{abstract}

Keywords: Discovery Learning, Learning Outcomes, mathematical concepts

\begin{abstract}
Abstrak: Penelitian ini bertujuan untuk mengetahui perbedaan tingat pemahaman konsep siswa pada mata pelajaran matematika yang menggunakan model discovery learning dan model pengajaran langsung pada siswa kelas $X$ SMK Khamas Asembagus tahun pelajaran 2017/2018. Penelitian ini merupakan jenis penelitian quasi experiment (kuasi eksperimen). Populasi dalam penelitian ini yaitu kelas X SMK Khamas Asembagus yang terdiri dari 3 kelas dengan jumlah 80 siswa. Sampel dalam penelitian ini yaitu kelas X TKJ 1 sebanyak 24 siswa sebagai kelas eksperimen dan kelas X MM sebanyak 31 siswa sebagai kelas kontrol. Pengumpulan data dalam penelitian ini dilakukan dengan menggunakan test dan selanjutnya dianalisis dengan uji t-test. Hasil analisis menunjukkan bahwa thitung $>t_{\text {tabel }}$ atau 3,198 > 1,6741, dapat disimpulkan bahwa terdapat perbedaan yang signifikan tingkat pemahaman konsep siswa pada mata pelajaran matematika antara yang menggunakan model pembelajaran discovery learning dan model pengajaran langsung.
\end{abstract}

Kata kunci: discovery learning, hasil belajar, konsep matematika

\section{PENDAHULUAN}

Matematika merupakan salah satu bidang studi yang diberikan semenjak duduk di bangku Sekolah Dasar (Harmony, 2012:12). Matematika sangat erat kaitannya dengan kehidupan sehari-sehari, karena segala jenis aktifitas dalam kehidupan sehari-hari selalu menuntut seseorang untuk menguasai matematika atau menghitung.

Kebanyakan siswa beranggapan bahwa matematika adalah pelajaran yang sulit untuk dipelajari dan dipahami. Keadaan inilah yang dapat menyebabkan 
hasil belajar matematika menjadi kurang. Banyak hal-hal yang mempengaruhi proses belajar mengajar di sekolah, baik dari luar siswa atau lingkungan maupun dari dalam diri siswa itu sendiri, hal tersebut bisa menjadi kendala dalam proses belajar siswa yang kemudian berimbas pada hasil belajar khususnya pada mata pelajaran matematika.

Peran guru dalam proses pembelajaran sangat penting karena guru merupakan salah satu faktor dalam menentukan pembelajaran di kelas maupun di sekolah. Berkaitan dengan masalah tersebut, setelah peneliti melakukan observasi pembelajaran matematika yang terjadi di kelas X MM SMK Khamas Asembagus ditemukan permasalahan antara lain, 1) Siswa cenderung pasif selama proses pembelajaran berlangsung, hal ini disebabkan karena dalam tahap persiapan maupun tahap penyampaian materi ajar kurang melibatkan siswa untuk berpartisipasi aktif, 2) Kemampuan siswa dalam menyelesaikan masalah atau soal masih kurang, penyebabnya siswa tidak memahami permasalahan dan model pembelajaran yang digunakan kurang bervariasi sehingga pemecahan masalah dalam pembelajaran matematika kurang optimal, 3) Siswa kurang aktif bertanya kepada guru tentang materi yang disampaikan.

Berdasar pada permasalahan di atas, peneliti ingin memperbaiki proses pembelajaran, yaitu dengan menerapkan model pembelajaran discovery learning dan model pengajaran langsung.

Discovery learning adalah proses belajar yang di dalamnya tidak disajikan suatu konsep dalam bentuk jadi (final), tetapi siswa dituntut untuk mengorganisasi sendiri cara belajarnya dalam menemukan konsep (Muhamad, 2016:12). Metode discovery (penemuan) merupakan komponen dari praktek pendidikan yang meliputi metode mengajar yang memajukan cara belajar aktif, berorientasi pada proses, mengarahkan sendiri, mencari sendiri dan reflektif.

Model discovery learning merupakan model pembelajaran yang memberikan kesempatan kepada siswa untuk menemukan informasi yang berupa konsepkonsep dan prinsip-prinsip dalam suatu proses mental, yang dilakukan melalui kegiatan percobaan sehingga anak memperoleh pengetahuan yang sebelumnya belum diketahuinya itu tidak melalui pemberitahuan, sebagian atau seluruhnya ditemukan sendiri.

Dalam pembelajaran matematika dengan menggunakan model pembelajaran discovery, diharapkan siswa dapat menemukan konsep-konsep dan prinsipprinsip melalui proses mentalnya sendiri. Dalam menemukan konsep, siswa melakukan pengamatan, menggolongkan, membuat dugaan, menjelaskan, menarik kesimpulan dan sebagainya untuk menemukan beberapa konsep atau prinsip.

Adapun langkah-langkah model pembelajaran discovery learning menurut Hamiyah dan Jauhar (2014:182) sebagai berikut: 1) mengidentifikasi kebutuhan siswa, 2) menyeleksi pendahuluan terhadap prinsip-prinsip, pengertian konsep dan generalisasi pengetahuan, 3) menyeleksi bahan, masalah/tugas-tugas, 4) membantu dan memperjelas tugas/masalah yang dihadapi siswa serta peranan masingmasing siswa, 5) mempersiapkan kelas dan alat-alat yang diperlukan, 6) mengecek pemahaman siswa terhadap masalah yang akan dipecahkan, 7) memberi kesempatan kepada siswa untuk melakukan penemuan, 8) membantu siswa dengan informasi/data jika diperlukan oleh siswa, 9) memimpin analisis sendiri (self-analysis) dengan pertanyaan yang mengarahkan dan mengidentifikasi masalah, 10) membantu 
siswa dalam merumuskan prinsip dan menggeneralisasi hasil penemuannya.

Adapun kelebihan model discovery learning menurut Sumantri (2010:143), sebagai berikut, 1) menekankan kepada proses pengolahan informasi oleh siswa sendiri, 2) membuat konsep diri siswa bertambah dengan penemuan-penemuan yang diperolehnya, 3) memiliki kemungkinan besar untuk memperbaiki dan memperluas persediaan dan penguasaan keterampilan dalam proses kognitif para siswa, 4) Penemuan yang diperoleh siswa dapat menjadi kepemilikannya dan sangat sulit melupakannya, 5) Tidak menjadikan guru sebagai satu-satunya sumber belajar, karena siswa dapat belajar memanfaatkan berbagai jenis sumber belajar.

Pengajaran langsung menurut Kardi (dalam Wenno, 2014) adalah model pengajaran yang berpusat pada guru, yang berarti bahwa guru bertanggung jawab untuk mengidentifikasi tujuan pembelajaran, dan kemudian memainkan peran aktif dalam menjelaskan konten atau keterampilan kepada siswa.

Langkah-langkah model pengajaran langsung (direct instruction) menurut Makahleh (2011) sebagai berikut, 1) mengukur kinerja siswa secara langsung dan akurat pra-mengajar sambil berkonsentrasi pada konsep-konsep dasar yang banyak dituntut oleh seorang siswa,, 2) tujuan ditetapkan secara akurat, diformulasikan secara operasional sehingga untuk memperkenalkan perilaku akhir yang diharapkan dari siswa, 3) menganalisis tugas instruksional dan mengatur elemen secara berurutan dan sistematis, 4) alokasikan waktu yang cukup untuk belajar tugas, 5) memberikan umpan balik mengenai kinerja siswa, 6) instruksikan siswa untuk mempraktekkan tugas yang dia kuasai lebih banyak melalui instruksi yang jelas, 7) menampilkan kinerja siswa dalam bentuk grafik yang sesuai, 8) menyediakan siswa dengan bentuk penyelesaian masalah yang tepat, mendukung siswa dalam pembelajaran mereka, menyediakan praktik yang sesuai dengan keterampilan khusus.

Kelebihan model pengajaran langsung menurut Suprihatiningrum (2014) sebagai berikut, 1) dalam model pengajaran langsung guru mengendalikan isi materi dari urutan informasi yang diterima oleh peserta didik, sehingga dapat mempertahankan fokus mengenai apa yang harus dicapai oleh peserta didik, 2) merupakan cara yang paling efektif untuk mengajarkan konsep dan keterampilanketerampilan kepada peserta didik yang berprestasi rendah sekali pun, 3) model ini dapat digunakan untuk membangun model pembelajaran dalam bidang studi tertentu. Guru dapat menunjukkan bagaimana suatu permasalahan dapat didekati, bagaimana informasi dianalisis, bagaimana suatu pengetahuan dihasilkan, 4) model pengajaran langsung lebih menekankan kegiatan mendengarkan, melalui ceramah, mengamati, demonstrasi, sehingga membantu peserta didik yang cocok belajar dengan cara-cara ini, 5) dapat memberikan tantangan untuk mempertimbangkan kesenjangan antara teori dan fakta, 6) model pengajaran langsung dapat diterapkan secara efektif dalam kelas besar maupun kelas kecil. Peserta didik dapat mengetahui tujuan-tujuan pembelajaran dengan jelas, 7) waktu untuk berbagi kegiatan pembelajaran dapat di kontrol dengan ketat, 8) dalam model ini penekanan pada pencapaian akademik, 9) kinerja peserta didik dapat dipantau secara cermat, 10) umpan balik bagi peserta didik berorientasi akademik, 11) model pengajaran langsung dapat digunakan untuk menekankan butir-butir penting atau kesulitan-kesulitan yang mungkin dihadapi peserta didik, 11) Model pengajaran 
langsung dapat menjadi cara yang paling efektif untuk mengajarkan informasi dan pengetahuan faktual dan terstruktur.

Hasil belajar matematika adalah hasil yang di dapat setelah mengalami proses pembelajaran matematika, dan bisa menilai seberapa jauh pengetahuan dan pemahaman siswa terhadap materi pembelajaran matematika, sehingga dapat membantu menyelesaikan permasalahan dalam kehidupan sehari-hari (Solihah, 2016:47).

Hasil belajar matematika merupakan hasil akhir yang diperoleh siswa setelah mengikuti proses belajar matematika yang ditandai dengan skala nilai berupa huruf atau simbol atau angka, sehingga dapat dijadikan tolak ukur berhasil atau tidaknya siswa tersebut dalam pembelajaran matematika. Dalam penelitian ini difokuskan pada salah satu ranah dalam teori hasil belajar yaitu pada ranah kognitif (Pengetahuan dan Pemahaman).

Menurut Wasliman (dalam Susanto, 2013), hasil yang dicapai oleh peserta didik merupakan hasil interaksi antara berbagai faktor yang mempengaruhi, baik faktor internal maupun eksternal. Adapun faktor internal dan eksternal yaitu, 1) Faktor internal merupakan faktor yang bersumber dari dalam diri peserta didik, yang mempengaruhi kemampuan belajarnya. Faktor internal ini meliputi: kecerdasan, minat, dan perhatian, motivasi belajar, ketekunan, sikap, kebiasaan belajar, serta kondisi fisik dan kesehatan 2) Faktor eksternal merupakan faktor yang berasal dari luar peserta didik yang mempengaruhi hasil belajar yaitu, keluarga, sekolah, dan masyarakat.

\section{METODE PENELITIAN}

Pada penelitian ini, peneliti menggunakan pendekatan penelitian kuantitatif. Untuk mengetahui pengaruh model pembelajaran Discovery Learning dan model Pengajaran Langsung, jenis penelitian yang digunakan adalah jenis penelitian quasi experimental atau penelitian kuasi eksperimen. Peneliti menggunakan desain Nonequivalent Control Group Design. Dalam penelitian ini peneliti hanya menggunakan posttes atau tes akhir setelah diberikan perlakuan.

Teknik penentuan lokasi yang digunakan oleh peneliti yaitu Purposive Sampling Area. Penelitian ini akan dilakukan di SMK Khamas Asembagus. Di sekolah tersebut terdapat 9 kelas, dengan 2 program keahlian yaitu Tekhnik Komputer Jaringan (TKJ) dan Multimedia (MM). Adapun populasi dalam penelitian ini adalah 80 siswa kelas $\mathrm{X}$ SMK Khamas Asembagus tahun pelajaran 2017/2018 yang terdiri dari kelas X TKJ 1 sebanyak 24 siswa, kelas X TKJ 2 sebanyak 25 siswa dan Kelas X MM sebanyak 31 siswa.

Penelitian ini menggunakan NonProbability Sampling yaitu teknik sampling yang tidak memberikan kesempatan (peluang) pada setiap anggota populasi untuk dijadikan anggota sampel (Riduwan dan Husdara, 2011:61). Adapun cara untuk menentukan ukuran sampel dalam penelitian ini, peneliti menggunakan rumus Nomogram Harry King. Adapun teknik pengumpulan data yang digunakan yaitu observasi, dokumentasi dan tes pilihan ganda. Pengujian instrumen dalam penelitian yaitu uji validitas, uji reliabilitas, analisis tingkat kesukaran dan daya pembeda soal.

Pengujian prasyarat analisis data yaitu uji homogenitas menggunakan varians terbesar dibanding varians terkecil dan uji normalitas menggunakan uji KolmogorovSmirnov kemudian dilanjutkan dengan uji t-test. 
HASIL DAN PEMBAHASAN

Hasil dan pembahasan pada akan diuraikan sebagai berikut.

penelitian ini

Tabel 1. Hasil Uji Homogenitas Nilai UTS Sebelum Diberikan Perlakuan

Test of Homogeneity of Variances

Nilai

\begin{tabular}{rrrr}
\hline Levene Statistic & df1 & df2 & Sig. \\
\hline .065 & 1 & 53 & .799 \\
\hline
\end{tabular}

Dari tabel 1 di atas dapat diketahui

bahwa nilai sig. 0,799 , dimana $0,799>0,05$

sehingga dapat disimpulkan bahwa data tersebut homogen.

Tabel 2. Hasil Uji Homogenitas Nilai Posttest Setelah Diberikan Perlakuan

\section{Test of Homogeneity of Variances}

\begin{tabular}{rrrr} 
Nilai & & & \\
\hline Levene Statistic & df1 & df2 & Sig. \\
\hline .001 & 1 & 53 & .980 \\
\hline
\end{tabular}

Berdasarhan hasil uji homogenitas bahwa kedua data memiliki varians yang setelah diberikan perlakuan baik kelas homogen. eksperimen maupun kelas kontrol diperoleh nilai sig $0,980>0,05$, dapat disimpulkan

Tabel 3. Hasil Uji Normalitas Nilai UTS Sebelum Diberikan Perlakuan One-Sample Kolmogorov-Smirnov Test

\begin{tabular}{cccc}
\hline & $\mathrm{N}$ & $\begin{array}{c}\text { Kls. X TKJ 1 } \\
\text { (Kelas Eksperimen }\end{array}$ & $\begin{array}{c}\text { Kelas X MM } \\
\text { (Kelas Kontrol) }\end{array}$ \\
\hline Normal & Mean & 24 & 31 \\
Parameters $^{\mathrm{a}, \mathrm{b}}$ & Std. Deviation & 6.157 & 72.84 \\
Most Extreme & Absolute & .174 & 6.100 \\
Differences & Positive & .153 & .219 \\
& Negative & -.174 & .126 \\
Kolmogorov-Smirnov Z & .854 & -.219 \\
Asymp. Sig. (2-tailed) & .459 & .1 .220 \\
\hline
\end{tabular}

Berdasarkan tabel 3 diatas dapat data baik kelas eksperimen maupun kelas diketahui bahwa kelas eksperimen memiliki kontrol berdistribusi normal. nilai sig. 0,459>0,05 dan kelas kontrol memiliki nilai sig. $0,102>0,05$, artinya

Tabel 4. Hasil Uji Normalitas Nilai Posttest Setelah Diberikan Perlakuan One-Sample Kolmogorov-Smirnov Test

\begin{tabular}{llrr}
\hline & \multicolumn{2}{c}{$\begin{array}{c}\text { Kelas X TKJ 1 } \\
\text { (Kelas Eksperimen) }\end{array}$} & $\begin{array}{c}\text { Kelas X MM } \\
\text { (Kelas Kontrol) }\end{array}$ \\
\hline $\mathrm{N}$ & Mean & 24 & 31 \\
Normal & Std. Deviation & 8.25 & 7.10 \\
Parameters ${ }^{\mathrm{a}, \mathrm{b}}$ & Absolute & 1.260 & 1.375 \\
Most Extreme & Positive & .204 & .228 \\
Differences & & .204 & .159
\end{tabular}


One-Sample Kolmogorov-Smirnov Test

\begin{tabular}{lrr}
\hline & $\begin{array}{c}\text { Kelas X TKJ 1 } \\
\text { (Kelas Eksperimen) }\end{array}$ & $\begin{array}{c}\text { Kelas X MM } \\
\text { (Kelas Kontrol) }\end{array}$ \\
\hline \multicolumn{1}{c}{ Negative } & -.168 & -.228 \\
Kolmogorov-Smirnov Z & .998 & 1.271 \\
Asymp. Sig. (2-tailed) & .272 & .079 \\
\hline
\end{tabular}

Berdasarkan tabel 4 diketahui bahwa kelas eksperimen memiliki nilai sig. 0,272 $>0,05$ dan kelas kontrol memiliki nilai sig. $0,079>0,05$, artinya data baik kelas eksperimen maupun kelas kontrol berdistribusi normal.
Setelah uji prasyarat (uji normalitas dan uji homogenitas) terpenuhi, maka selanjutnya dapat dilakukan uji hipotesis menggunakan uji $t$-test.

Tabel 5. Hasil Perhitungan Uji t-test Hasil Belajar Siswa (Posttest) Group Statistics

\begin{tabular}{llrrrr}
\hline & Metode & $\mathrm{N}$ & $\mathrm{Mean}$ & Std. Deviation & Std. Error Mean \\
\hline \multirow{2}{*}{ Nilai } & Discovery Learning & 24 & 8.2500 & 1.25974 & .25714 \\
& Pengajaran Langsung & 31 & 7.0968 & 1.37489 & .24694 \\
\hline
\end{tabular}

Independent Samples Test

\begin{tabular}{|c|c|c|c|c|c|c|c|c|c|c|}
\hline & & $\begin{array}{r}\text { Leve } \\
\text { Test } \\
\text { Equali } \\
\text { Varia }\end{array}$ & $\begin{array}{l}\text { ne's } \\
\text { for } \\
\text { ity of } \\
\text { inces }\end{array}$ & & & t-test & for Equality & of Means & & \\
\hline & & & & & & & & & $\begin{array}{r}95 \% \text { Cor } \\
\text { Interval } \\
\text { Differ }\end{array}$ & $\begin{array}{l}\text { fidence } \\
\text { of the } \\
\text { ence }\end{array}$ \\
\hline & & $\mathrm{F}$ & Sig. & $\mathrm{T}$ & df & $\begin{array}{l}\text { Sig. (2- } \\
\text { tailed) }\end{array}$ & $\begin{array}{c}\text { Mean } \\
\text { Difference }\end{array}$ & $\begin{array}{l}\text { Std. Error } \\
\text { Difference }\end{array}$ & Lower & Upper \\
\hline Nilai & $\begin{array}{l}\text { Equal } \\
\text { variances } \\
\text { assumed }\end{array}$ & .001 & .980 & 3.198 & 53 & .002 & 1.15323 & .36057 & .43002 & 1.87643 \\
\hline & $\begin{array}{l}\text { Equal } \\
\text { variances not } \\
\text { assumed }\end{array}$ & & & 3.235 & 51.441 & .002 & 1.15323 & .35651 & .43765 & 1.86881 \\
\hline
\end{tabular}

Berdasarkan tabel 5 terlihat bahwa nilai $t_{\text {hitung }}$ diperoleh 3,198 dengan sig.(2tailed) 0,002. Pada taraf signifikan 0,05 diperoleh $t_{\text {tabel }}=1,6741$. Maka dapat disimpulkan bahwa $t_{\text {hitung }}>\mathrm{t}_{\text {tabel }}$ atau 3,198 $>1,6741$ terdapat perbedaan antara kelas eksperimen dan kelas kontrol. Hal ini juga ditunjukkan oleh nilai sig.(2-tailed) $=0,002$ $<0,05$ maka $\mathrm{H}_{0}$ ditolak. Sehingga dapat disimpulkan bahwa terdapat perbedaan yang signifikan hasil belajar siswa pada mata pelajaran matematika antara yang menggunakan model pembelajaran discovery learning dan model pengajaran langsung

Dari rata-rata nilai hasil belajar siswa pada kelas eksperimen sebesar 8,2500 artinya ada peningkatan hasil belajar siswa setelah pembelajaran menggunakan model pembelajaran discovery learning. 
Sedangkan rata-rata nilai hasil belajar siswa kelas kontrol sebesar 7,0968 artinya juga ada peningkatan hasil belajar siswa setelah pembelajaran menggunakan model pengajaran langsung. Berdasarkan rata-rata nilai hasil belajar siswa yang diperoleh setelah perlakuan menunjukkan bahwa nilai rata-rata kelas eksperimen yang menggunakan model pembelajaran discovery learning lebih tinggi dibanding kelas kontrol yang menggunakan model pengajaran langsung.

Berdasarkan hasil analisis data dan pengujian hipotesis mengenai pengaruh model pembelajaran discovery learning dan model pengajaran langsung terhadap hasil belajar siswa pada mata pelajaran matematika kelas $\mathrm{X}$ SMK Khamas Asembagus tahun pelajaran 2017/2018 didapatkan hasil penelitian 1) Terdapat perbedaan yang signifikan hasil belajar siswa pada mata pelajaran matematika antara yang menggunakan model pembelajaran Discovery Learning dan model Pengajaran Langsung kelas X SMK Khamas Asembagus tahun pelajaran $2017 / 2018$, 2) berdasarkan rata-rata nilai hasil belajar siswa yang menggunakan model pembelajaran discovery learning lebih tinggi dibandingkan rata-rata nilai hasil belajar siswa yang menggunakan model pengajaran langsung.

\section{SIMPULAN}

Berdasarkan hasil analisis data, diperoleh $t_{\text {hitung }}>t_{\text {tabel }}$ atau 3,198 $>1,6741$ dan nilai signifikansinya $0,002<0,05$ maka $\mathrm{H}_{0}$ ditolak, artinya terdapat perbedaan yang signifikan hasil belajar siswa antara kelas eksperimen yang menggunakan model pembelajaran discovery learning dan kelas kontrol menggunakan model pengajaran langsung. Dilihat dari nilai rata-rata hasil belajar siswa kelas eksperimen yang menggunakan model pembelajaran discovery learning sebesar 8,2500 dan kelas kontrol yang menggunakan model pengajaran langsung sebesar 7,0968 ini menunjukkan bahwa model pembelajaran discovery learning lebih cocok digunakan dalam pembelajaran matematika siswa kelas X SMK Khamas Asembagus dibanding model pengajaran langsung, hal ini disebabkan karena dalam proses pembelajaran, penggunaan model discovery merupakan model pembelajaran yang banyak melibatkan siswa dalam kegiatan belajar mengajar. Dengan demikian, model pembelajaran discovery learning dapat menjadi salah satu alternatif bagi para guru mata pelajaran matematika dalam meningkatkan hasil belajar siswa.

Demi keberhasilan pelaksanaan kegiatan proses belajar mengajar, adapun saran yang dapat diberikan sehubungan dengan penelitian ini adalah, pertama, model pembelajaran discovery learning merupakan salah satu alternatif dalam meningkatkan hasil belajar siswa khususnya pada mata pelajaran matematika, karena dalam proses pembelajaran discovery learning banyak melibatkan siswa untuk lebih aktif dalam mengembangkan pengetahuannnya, kedua, bagi guru diharapkan dapat menggunakan model pembelajaran yang lebih inovasi dalam kegiatan proses belajar mengajar agar para siswa lebih aktif dan antusias dalam mengikuti pelajaran, salah satunya yaitu model pembelajaran discovery learning. 


\section{DAFTAR RUJUKAN}

Hamiyah dan Jauhar. (2014). Strategi Belajar Mengajar di Kelas. Jakarta: Prestasi Pustakaraya.

Harmony. (2012). Pengaruh Kemampuan Spasial Terhadap Hasil Belajar Matematika Siswa Kelas VII SMP Negeri 9 Kota Jambi. Edumatica, 2(1), 11-19.

Makahleh. (2011). The Effect Of Direct Instruction Strategy On Math Achievement Of Primary 4th And 5th Grade Students With Learning Difficulties. International Education Studies, 4(4), 199-205.

Muhamad. (2016). Pengaruh Metode Discovery Learning untuk Meningkatkan Representasi Matematis dan Percaya Diri Siswa. Jurnal Pendidikan Universitas Garut, 9(1), 9-22.

Riduwan dan Husdara. (2011). Belajar Mudah Penelitian: Untuk GuruKaryawan dan Penelitin Pemula. Bandung: Alfabeta.
Solihah. (2016). Pengaruh Model Pembelajaran Teams Games Tournament (Tgt) Terhadap Hasil Belajar Matematika. Jurnal SAP, 1(1), 45-53.

Sumantri. (2010). Strategi Belajar Mengajar. Bandung: CV Maulana.

Suprihatiningrum. (2014). Strategi Pembelajaran Teori dan Aplikasi. Yogyakarta: Ar-Ruz Media.

Susanto. (2013). Teori Belajar dan Pembelajaran di Sekolah Dasar. Jakarta: Kencana.

Wenno. (2014). Direct Instruction Model To Increase Physical Science Competence Of Students As One Form Of Classroom Assesment. International Journal of Evaluation and Research in Education (IJERE), 3(3), 169-174. 